\title{
CURRÍCULO ESCOLAR: SABERES LOCAIS E MULTIPLICIDADES
}

\author{
AUTOR: KAROLLYNE SARMENTO DE PAULA \\ CO-AUTOR/OREINTADOR: ELIANA POVOAS PEREIRA ESTRELA BRITO
}

O projeto de pesquisa intitulado: Currículo e Cultura: Ressignificações nas aprendizagens dos Anos Finais do Ensino Fundamental sofreu modificações que alterou o plano de trabalho denominado: Currículo escolar: saberes locais e multiplicidades. A pesquisa focou o primeiro ano do currículo do ensino médio, em detrimento do ensino fundamental, de uma escola da rede estadual buscando compreender a nova estruturação curricular proposta para este nível de ensino. Tendo como referência a Base Nacional Comum Curricular-BNCC, centrou-se no componente curricular "Projeto de Vida e Cidadania". É importante frisar que a Secretaria da Educação do Estado da Bahia - SEC, disponibilizou um Documento Orientador quanto as mudanças na etapa do Ensino Médio, iniciadas em 2020, nas $1^{\text {a }}$ séries das Escolas-piloto, que deverão englobar as três series até 2022, enquanto as demais escolas terão até 2023 , visto que a transição iniciará em 2021. Este documento contém a proposta de arquitetura curricular do novo ensino médio no estado da Bahia: a parte comum obrigatória trazida pela BNCC, e a parte flexível composta por Unidades Curriculares Obrigatórias intituladas Núcleo Comum, e as Unidades Curriculares Eletivas, que correspondem ao primeiro passo para a implementação dos itinerários. Os alunos deverão cursar duas eletivas optativas, e a escola deverá ofertar uma quantidade mínima de eletiva proporcional a quantidade de turmas existentes, gerando a possibilidade de escolha dos estudantes. Ainda está previsto uma terceira eletiva EAD que deverá ser ofertada por parceiros institucionais por meio da utilização de tecnologias (ensino a distância). O Núcleo Comum é composto pelas unidades: Formação Cientifica, Produção e Interpretação Textual e o Projeto de Vida e Cidadania. Na cidade de Porto Seguro/BA a escola piloto é o Colégio Modelo Luís Eduardo Magalhães no qual fora realizada a pesquisa, buscando analisar o documento orientador e as medidas adotadas. A SEC disponibilizou, orientações didáticas-metodológicas para a unidade curricular Projeto de Vida e Cidadania; dividido em três módulos que deverão ser trabalhados ao longo do primeiro ano do ensino médio, são eles "Consciência Pessoal'",'Eu e o outro: à construção da sociabilidade" e "Planejamento e Estratégia", os módulos perpassam a dimensão, pessoal, social, cidadã e profissional.

Palavras-chave: Ressignificações curriculares, Aprendizagens, Matriz Curricular. 